\title{
THE MINUTES OF THE TWENTY-FIFTH ANNUAL MEETING OF THE CANADIAN SOCIETY OF FOREST ENGINEERS
}

$\mathrm{T}$

HE 25th annual meeting of the Society was held in the Windsor Hotel, Montreal, January 26th and 27th. The session commenced with a dinner in the evening, at which Clyde Leavitt, Assistant Dean of the New York State College of Forestry, and for many years treasurer of the Society, was the honored guest. In the absence of the President, Mr. G. C. Piche, Dr. Howe occupied the chair and acted as toast-master. Telegrams of regrets at not being present and extending best wishes to Mr. Leavitt were read from G. C. Piche and Avila Bedard.

After dinner was served the chairman called the meeting to order and explained the purpose of the gathering, and outlined the work which Mr. Leavitt had performed in Canada during the past twenty years. He spoke of his personal acquaintance with Mr. Leavitt and regretted that it was necessary for the Dominion Government to dispense with his services at the time it did. He then read an illuminated address, which had been prepared for the occasion, as follows:

\section{THIS SCROLL OF RECOGNITION IS PRESENTED BY THE CANADIAN SOCIETY OF FOREST ENGINEERS AS A TOKEN OF DEEP APPRECIATION TO CLYDE LEAVITT, B.A., M.S.}

for his earnest and unceasing labour during the past twenty years in pro. moting the ideals and applications of Forestry in Canada; as one time President, Secretary and Treasurer of the Society; as Chief Forester of the Commission of Conservation, and Chief of the Fire Inspection Department of the Board of Railway Commissioners; as an investigator and executor of forest research and stock-taking surveys; as a remarkably successful administrator in reducing the number of fires along the railways; as a writer of governmental reports of high quality and literary value; as a friend and counsellor of young foresters.

In acknowledgment of these and many other services to Forestry in Canada, the President and Secretary of the Canadian Society of Forest Engineers as directed by a unanimous vote at the twenty-fifth annual meeting of the Society held in Montreal on the twenty-sixth day of January, nineteen hundred and thirty-three, have affixed their signatures.

\section{G. C. PICHE,}

President.

Arthur Herbert Richardson, Secretary. 
Following the reading of this Mr. H. C. Johnston, who was Mr. Leavitt's assistant on the Board of Railway Commissioners for Canada, in the Fire Inspection Department, read an address from Mr. Leavitt's old staff, as follows:

CLYDE LEAVITT

\section{GREETINGS!}

We, the Staff, Fire Inspection Department, of the Board of Railway Commissioners for Canada, the Officers of the various Dominion and Provincial Forest Protective Organizations in co-operation, and Associates, desire to express our sincere appreciation of the many years of association with you as Chief Fire Inspector in directing the work of the Fire Inspection Department since its inception in 1912.

On your retirement from the Civil Service of the Dominion of Canada, after twenty years of faithful and efficient service, it would appear that some tangible expression of our esteem is in order.

We all feel a distinct personal loss in your retirement and owe you a debt of gratitude for what you have done for forest protection in general and railway fire prevention in particular. In this connection, we cannot do better than quote the following extract taken from the Proceedings and Resolutions of the Second British Empire Forestry Conference held in Canada in 1923, wherein it is stated as follows:

"It should be pointed out also that mere numerical superiority does not indicate that in Canada to-day railways are responsible for the greater part of our annual fire losses. The individual railway fire is, on the average, proportionally very much smaller than the average forest fire arising from other causes. This excellent condition is a direct result of co-operation between the railways and forest portective organizations directed by the Chief Fire Inspector of the Board of Railway Commissioners, and functioning under the regulations of that authority. The truth of the matter is that railways to-day are a minor factor in forest fire damage. This situation has developed within the last ten years and stands as a monument to the value of co-operative effort, and incidentally to the services of Mr. Clyde Leavitt, Chief Fire Inspector of the Board of Railway Commissioners."

You have not less successfully performed your duties as a Citizen and Fellowman and you leave behind a record that will be difficult to duplicate and we express the wish that you will be long spared to carry on in your chosen field of endeavor and for these reasons we bear testimony in these conditions.

Presented to

Clyde Leavitt,

January 26, 1933. 
Appended to this was a list of officers of the Board's Fire Inspection Department, Dominion and Provincial Forest Protection Services, National Parks Branch, and others who were associated with Mr. Leavitt in his work.

Together with the testimonial, Mr. Johnston also presented Mr. Leavitt with a sterling silver tea service and serving tray.

Following these presentations Mr. Leavitt, with much feeling, responded to the two addresses and thanked the members of the Society and his old staff, through Mr. Johnston, for the great kindness which they had shown him on this occasion. He stressed the years of his forestry work in Canada and mentioned the names of many foresters and others with whom he had been associated, and the splendid co-operation which had been given him at all times. He regretted very much having to leave Canada, but stated that he was comfortably situated in Syracuse, in a type of work which is dear to his heart.

Following Mr. Leavitt's remarks the chairman called on several foresters present to speak. These included E. J. Zavitz, E. H. Finlayson, Ellwood Wilson, Otto Shierbeck, D. R. Cameron, Professor Gibson, R. L. Kellogg and several others.

The morning session, January 27th, opened with Mr. Piche in the chair and, after welcoming the members and visitors to the meeting, he addressed the gathering as follows:

Gentlemen:-

I must apologize for not having been present at our annual dinner, but as the house was sitting I was quite unable to do so. I wish to thank you for the great honour you have bestowed on me, by electing me president of your society. I will do my best to justify the confidence you have placed in me. At the same time I would much appreciate the help and co-operation of each individual member, and that of the Society as a whole.

We must not forget that we owe a real debt of gratitude to my predecessor Caverhill, whose work on behalf of the Society during this period of depression, in spite of rather poor health, has set me an example which I will endeavour to follow.

I deeply regret that my absence should have prevented me from personally joining you in doing honour to Clyde Leavitt. However, I will take this opportunity of voicing my sincere admiration for the work carried on by him as the head of the Railway Commission, for which he gave devoted service for the best twenty years of his life.

These are trying times for everybody, but there is still hope that the lumber trade will be able to regain some of its former prosperity. The English market, which at present is almost closed to us, would, with the 
rise of the pound, combined with the preference of $10 \%$ be a very advantageous one. A serious blow to our export trade was the imposing of an additional $\$ 3.00$ per $M$. on Canadian lumber exported to the United States; this has shut us out of a market where we sold yearly over a billion feet. We hope that the new American administration will revise this and allow, as before, the free movement of a part of our output towards its natural market.

The pulp and paper industry is still in a chaotic condition with very little hope of any rapid recovery. Fifty per cent of the mills are not able to meet the interest on their bonds which will automatically wipe out the present capitalization; like Atlas, the industry crumbles under its financial burden. Therefore the real owners of the industry should step in and openly declare their policy.

This is not the first time that our lumber industry has been almost at a standstill. In 1861 our export of forest products was almost nil. What happened? Our forefathers went to Europe for their market. Well-the same holds good for to-day. We must get into direct personal touch with the European user of our forest products. If required new methods of merchandising should be introduced and unhesitatingly employed.

There is another factor which has to be considered with respect to the state of the lumber market at the present time, that is the use of wood substitutes. The American lumber industry, through various forest laboratories, is making a great effort to restore to lumber the position that it formerly held. In the same way the Quebec Forest Products Commission-though only organized fifteen months ago-is doing the same thing. To cite only one instance, the use of wood for fuel. Last Octor ber the people in the Montreal district were urged to supplement their coal supplies by the use of wood. So this winter saw a great increase of activity in every Laurentian Mountain village, resulting in an increased cordwood cut of over 100,000 cords valued at several hundred thousand dollars.

The forest industry is the basic industry of Canada. It is the sale of wood products which keep our rural districts happy and prosperous. So I believe that we should insist on the recognition of this fact by the var. ious Governments as well as the necessity of supportnig our forest administration by larger budgets. Money could easily be diverted from direct relief, to the building of forest roads, to the planting of waste lands, and areas ruined by shifting sands. These are real investments. The money spent is not sunk forever, but only lent for the restoration of land temporarily ruined by unwise management.

There is now a Forestry organization employing trained foresters in 
every province of the Dominion. A start has also been made by private companies who are calling more and more upon foresters to direct their logging operations. The good results obtained by men like Messrs. Gilmour, Delahey, Boisvert, J. Wilson, Schanche, Davis, Munroe, etc., prove that forest engineers are well qualified to handle this work. It is only logical that the man who has prepared the maps of the territory, studied the distribution of the forest, and the maturity of each stand, should determine how and when they should be lumbered. His presence at the head of a lumber department would also facilitate the proper and complete removal of the forest crop, and the preservation of the younger stands in order to keep the whole territory on the highest produtcive basis. This is the crucial point in any forest proposition. It is the duty of every forester in charge of a forest property to organize his operations so that he may increase the annual yield instead of reducing it. This is the idea to sell to our employers. Even in these hard times, if you can demonstrate that the expenditures you recommend will not only serve for better protection and exploitation but will finally bring in more revenue, that instead of having a crop of 10,25 or 50 F.B.M. per acre, you can raise it to 100 , 200 or even 300 F.B.M. per acre; then you have a sound proposition which will never be refused by any good business man.

The essential thing is that a forest, whether managed by a Government, a lumber company or a paper company, should be considered as a complete unit, absolutely distinct from the plant. Each section of the work should have its own budget. For instance, the forester should deliver wood at the mill in competition with the price at which it can be bought. A program of operation should be planned and cutting could be carried on without the extreme variation in costs that are found at present. In provincial administration we often find fish and game departments distinct and separate from forest departments. It would reduce cost to have all matters pertaining to the forest set together as in Europe.

It is essential that the price of wood be reduced, but as the papers by Mr. Delahey and Mr. John Wilson deal in a very thorough manner with this subject it will not be necessary for me to do more than touch on one factor in logging operations which is too often, neglected. That is the condition of the forest worker under the jobbing system. The condition of the lumber jack when lumber companies were operating themselves was excellent. To-day, however, not only has the forest worker suffered from a reduction in wage, but from a real deterioration of living conditions as well. As this is due to a pernicious system which encourages the jobber, it would be well to do away with him entirely and to establish a method which will give a fair salary and good living conditions to the woods 
worker. In this way we shall retain his loyalty and his devotion to our work.

This concludes my message to you for the time being, but as time goes on I hope that we will be working together in an attempt to put across to the general public what our forest policy is accomplishing. Not only must we be ready to defend our ideas and our cause, but we must maintain an active propaganda on our work. Lest any of you deem this unnecessary, I will conclude my remarks by repeating a poem which I discovered in "Wood Construction."

If you can see what some folks call "depression"

As nothing but a spin of Fortune's wheel;

If you can keep your poise and self-possession

No matter what you think or how you feel;

If you can rise above the mess and muddle, If you can glimpse a rainbow through the clouds

When Doubt and Dread and Fear are in a huddle And Hope is being measured for a shroud;

If you can keep a saving sense of humour For stories that are slightly inexact;

If you can disregard Report and Rumor And not accept a statement as a fact;

If you can spread the gospel of successes, If you can stir the spirit that instills, The latent lift in lathes and looms and presses And lift the stream above a thousand mills; If, briefly, you can spend an extra dollar; If you can pry the sacred Roll apart And buy another shirt or shoe or collar And act as if it didn't break your heart; If you have faith in those with whom you labor, And trust in those with whom you make a trade; If you believe in friend and next-door neighbor And heed examples pioneers have made; If you expect the sun to rise tomorrow; If you are sure that somewhere skies are blueWake up and pack away the futile sorrow For better days are largely up to you.

Before calling for the presentation of the first paper, the Resolution Committee was appointed as follows: Messrs. Howe, Shierbeck, J. Roy and MacDonald. 
The first paper, "The Economic Aspect of a Working Plan on an Experimental Forest" was read by R. H. Candy, Dominion Forest Service, Ottawa. Comments were made on this paper by Professor Gibson and Ellwood Wilson, and it was pointed out that here in Canada was an example where forestry and silviculture was actually being practised but it was regretted that costs had not been included in the paper. Mr. Piche pointed out that a great deal of the material taken from this forest was used for fuel and informed the audience that in his province of Quebec many people were substituting wood in place of coal, thus giving more work to the farmers.

At this point Mr. Kilby introduced Mr. Rochester of the Canadian National Railways, who had been associated formerly with Messrs. Leavitt and Mills. Mr. Rochester brought greetings from his company and outlined some of the difficulties the railways are having at the present time.

The next paper, "Forest Boundaries in British Columbia," by J. D. Mulholland, Forest Branch, British Columbia, was read by R. D. Craig, in the absence of Mr. Mulholland.

The paper "Direct Seeding in Ontario" was presented next, as it was felt that Mr. Nix' paper should be read at the same time as Mr. Delahey's. Following Mr. Bayly's paper comments were made by Mr. Zavitz, who pointed out the necessity of experiments in direct seeding because quite often the public do not understand the reason for growing trees in nurseries, thinking that reforestation could be handled entirely by direct seeding methods. Lane, Piche and Wilson contributed to the discussion and mentioned seeding work which had been carried out in Quebec and pointed out that on most areas treated in this way there was a delayed germination and, while the results were not seen the first two or three years, good results were often obtained by a later count, six or seven years after the sowing.

Veness mentioned the seeding carried on by the Dominion Service in New Brunswick. Messrs. Irwin and Candy also contributed to the discussion.

The next paper was one entitled "Will Technical Control in Logging Open the Door to Better Silvicultural Management," by L. A. Nix, Bathurst Power and Paper Company, Bathurst, N.B. In the absence of Mr. Nix this paper was read by L. S. Webb.

Following this Mr. Delahey read his paper, after which J. O. Wilson lead the discussion. Mr. Wilson's discussion was so informing that he was asked to prepare it in the form of an article and this, together with the other papers, appears in the current number of the Chronicle. The other members contributing to the discussion were Koroleff, of the Pulp and Paper Association, and Rothery, of the International Paper Company.

The afternoon session commenced with the reading of reports, first the Secretary's, then the Treasurer's. These were both accepted as read, and will 
be found elsewhere in this number. One item of business which arose from the Treasurer's report was that the Treasurer of the Society be bonded. This was suggested by Mr. Cameron and carried by the meeting.

The question of arrears of several members was brought up, and it was decided to extend one year's grace to those in arrears, in consideration of the fact that many of these members are out of work.

The Resolution Committee then made its report. There was considerable discussion regarding certain resolutions, some of which were sent back to

the Committee for revision. A list of these, as they were finally amended and passed, are as follows:

\section{RESOLUTIONS}

No. 1-Whereas the forests of Canada are one of the most important natural resources for the providing of labour, and during these difficult times are fulfilling these demands upon them to the utmost;

$\mathrm{Be}$ it resolved that in the opinion of the Canadian Society of Forest Engineers, a considerable part of the relief money paid out of the Federal and Provincial funds should be expended on work that will benefit our forests, such as reforestation and fire prevention, the latter including slash disposal, where such slash is a fire menace, construction of fire trails, construction of fire towers, building of telephone lines, thereby putting back into the forests some of the capital taken out of them through the furnishing of labour to the unemployed.

No. 2.-Whereas our forest industries are second in importance only to the agricultural industry in the Dominion, and whereas the appropriations hitherto made by the Federal government have been entirely inadequate for the conduct of investigative, experimental and research work basic to the solution of the fundamental problems facing the industry; and whereas the work of the Federal Forest Service does not overlap, but is thoroughly co. ordinated with the scientific work of the provincial services;

Now, therefore, be it resolved by the C.S.F.E. that in its opinion the Federal appropriations for such work should be augmented so that a more comprehensive programme of work in collecting and disseminating information regarding the forest resources and industries, and for the conduct of experimental forestry, for investigating and combating forest diseases, for cooperative stock-taking of forest resources, and for the maintenance of a more comprehensive programme of work in the Forest Products Laboratories of Canada;

$\mathrm{B} e$ it resolved further that the President of this Society and two other members to be selected by him, be delegated to wait upon the Right Honourable R. B. Bennett, Prime Minister of Canada, and if found appropriate, upon 
the Minister of Finance, to urge upon him, or them, the importance of the work and the necessity for appropriation more in keeping with the stature of the industry and of the importance of the forest resource upon which the industry is based.

No. 3.-Whereas unemployment in the profession of forest engineers is 50 severe that the profession is in dire straits;

Be it resolved that an Employment Committee be appointed by the Society of Canadian Forest Engineers, for the purpose of assimilating data regarding all unemployed Canadian Forest Engineers, for the purpose of obtaining information regarding vacant posititons in the forest services and forest indus. tries, said information to be published in the Forest Chronicle, and for the purpose of creating new positions by agitation and interviews with the heads of forest services and presidents of pulp and paper companies and presidents of large lumber concerns; also through the conduction of a press campaign, thereby informing the public of the necessity of the employment of forest engineers, if our forest wealth is to be conserved.

No. 4.--Resolved that the papers to be read at the annual meeting be reduced in number to permit of discussion and that such papers be printed and distributed to members of the Society prior to the meeting.

No. 5.-Resolved that the C.S.F.E. representing the forestry profession in Canada expresses its disapproval of the moving of the headquarters of the Canadian Forestry Association from Ottawa to Montreal and of the removal of Mr. Gordon M. Dallyn from the active administration of the activities of the Association including the editing of Forest and Outdoors, or any lessening of his active association in the work of the Canadian Forestry Association.

And further, that the C.S.F.E. feels that the Association is not giving the support it should to the fundamental principles of forestry, such as silviculture and intelligent forest management, and would request that more attention be paid to this phase of the forestry problem in the Magazine.

No. 6.-Resolved, that at least once every two years the Editor of the Chronicle print a complete list of the names of the members, their last known address and the name of the employer of each.

No. 7.-Resolved, that at each election of officers by mail the ballot papers be accompanied by a condensed statement about each candidate stating the date of graduation, the name of the Forest School, past and present position and name of employer.

No. 8.- Re menace of the white pine blister rust in Canada.

Whereas the insidious inroads of the blister rust in the valuable white pine resources of Canada are everywhere making headway from the Atlantic coast to the Lake of the Woods and also in British Columbia, and 
Whereas, in the United States the problem of controlling this destructive forest enemy has been organized on a co-operative basis between the various states and the Federal government, with marked success, through the agency of the White Pine Blister Rust Bureau at Washington;

Therefore be it resolved by this Society that the federal and provincial forest authorities concerned be urged to institute comparable action in this country, without further delay.

No. 9.-Resolved that the C.S.F.E. assembled in annual meeting extend its appreciation of the services rendered by the retiring executives of the Society, especially to the retiring President and Treasurer.

Following the Resolutions Committee's report, R. D. Craig moved the following notices of motion, to change Article 6, Section 3, of the Constitution, to read as follows: "The officers of the Society shall be elected annually, by letter ballot."

The next paper on the programme was one entitled "Farm Woodlots," which described the work of utilization of farm woodlots in New Brunswick. This was illustrated with lantern slides.

The last paper was entitled "The Relation Between Collecting Date and Maturity of Seed of Red Pine," by A. S. L. Barnes, of the Ontario Forestry Branch, Toronto. This was a careful study of the topic as described by the title, and it was to be regretted that more time was not available for dis: cussion.

As the afternoon session was running rather late, and some of the members wished to get away, the last two papers, namely, "The Economic Approach to Forestry" by L. R. Scheult, and "Disease as a Factor in the Transition of Pine to Stable Type," by W. R. Haddow, University of Toronto, were taken as read.

After words of appreciation on the part of the chairman for the assistance which the members had given in carrying through the sessions, the President adjourned the twenty-fifth annual meeting. 